Historic, Archive Document

Do not assume content reflects current scientific knowledge, policies, or practices. 

MON-WARBATTEE.-We, the Western Seea \& Irrigation Company, exercise great care to have all iseeds pure and rellable, but do not give any warranty expressed or Implled, as to description, quality, productiveness, or any other matter of any seeds, bulbs, or plants we send out, and we will not be in any way responsible for the crop. If the purchaser does not accept the goods on these terms, they aro at once to be returned.

LOWELL EMERSON

President \& Treasurer.
ESTABLISHED 1887 INCORPORATEO 1894
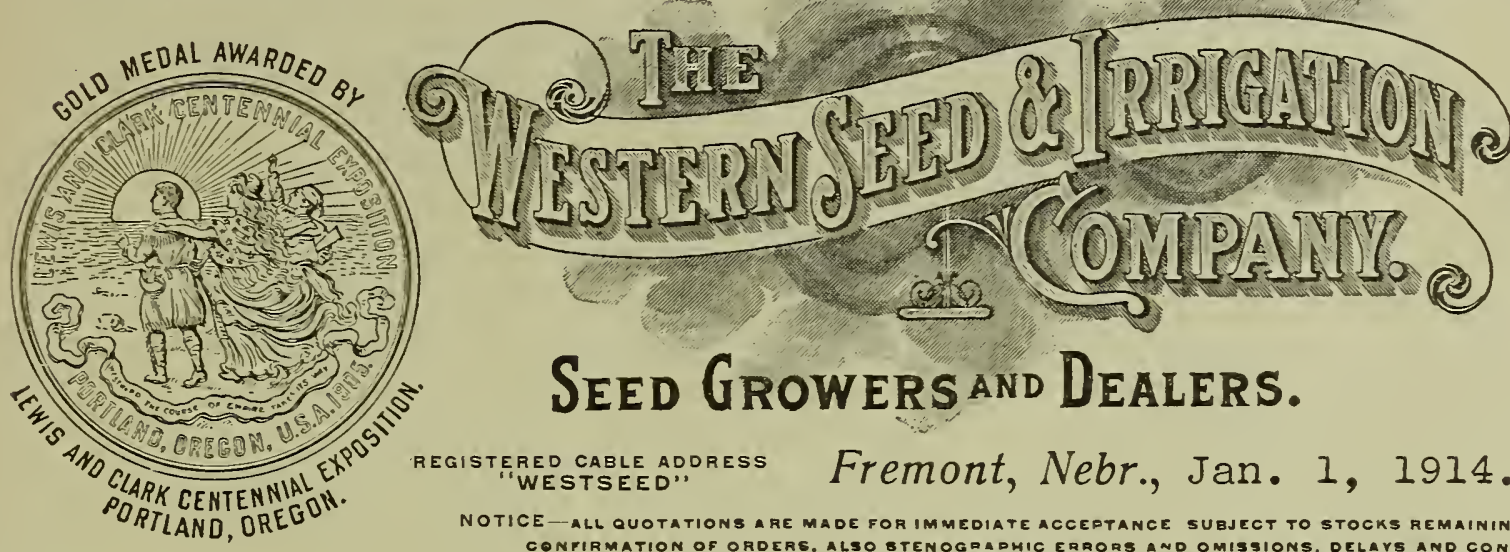

\section{SeEd Growers and Dealers.}

REGISTERED CABLE ADDRESS WESTSEED'

Fremont, Nebr., Jan. 1, 1914. WILEIAM EMERSON 1923

NOTICE - ALL QUOTATIONS ARE MADE FORIMMEDIATE ACCEPTANCE SUBJECT TO STOCKS REMAINING UNSOLD AND

CONFIRMATION OF ORDERE, ALSO BTENOGRADMIC ERRORS AND OMISSIONS, DELAYS AND CONTINGENCIES

TO THE WHOLESALE TRADE:

- crond ouR CONTROL.

We are pleased to offer the following kinds and quantities of seed

Sweet Corn which we expect to have in excess of our contract orders, grown from selected seed stocks furnished the growers by ourselves.

We are also pleased to quote the following seed Field Corn which we can obtain from growers who have produced the crops, independent of contracts, and which we believe will show a high percentage of germinating vitality and be suitable for seed purposes, viz.:

Bus.

$$
\text { Sweet Corn }
$$

50 Crosby's Original Strain $\$ 2.00$

50 Howling Mob

50 Kendall's Giant Early

50 Champion Early

300 Early Minnesota

100 Perry's Hybrid

200 Black Mexican
Bus. of 50 Ibs.

2.25

1.75

1.75

1.65

1.75

1.65

\section{Field Corn}

Bus.

Yellow Dent

2000 King of the Earliest

3000 Pride of the North

1000 Reid's Yellow Dent

1000 Iowa Gold Mine

2000 Improved Leaming

500 Mastodon

1000 Golden Rod
Bus. of 56 Ibs.

$\$ 1.05$

1.05

1.00

1.00

1.00

1.05

1.05
Measured Bus.

20 Mammoth Late

40 Egyptian

$\$ 1.90$

1.90

2.00

2.00

2.00

150 Zig Zag Evergreen

300 Stowell's Evergreen XX

Select

500 Evergreen Sweet Fodder
2.25

1.40
White Dent

200 Adam's Extra Early

1.10

200 Adam's Large Early

1.10

500 Clark County Champion 1.00

1000 Wisconsin White Dent 1.00

1000 Iowa Silver Mine

1.00

1000 Champion White Pearl

1000 Red Cob White

1.00

1.05

WRITE OR WIRE FOR SPECIAL PRICES FOR CAR LOAD LOTS.

THE PRICES FOR THE SWEET CORN ARE FOR HANDPICKED STOCKS; FIELD CORN ARE FOR THE COMMERCIAL GRADE, NOT HANDPICKED. IF HANDPICKED STOCKS ARE REQUIRED, ADD 25c PER BU. TO THE PRICES QUOTED TO COVER THE COST OF EXTRA HANDLING AND HANDPICKING.

The quotations are made for immediate acceptance and subject to the stocks remaining unsold; delivery F. 0. B. Fremont; sacks extra at Fremont values; shipment as soon as possible--not later than Jan. 31 , 1914 ; terms, draft attached to bill of lading payable upon arrival of the corn. Hoping to be favored with a memo. of your requirements and your esteemed orders which we will give our careful attention, we remain Yours truly, WESTERN SEED \& IRRIGATION CO. 
